\author{
S.A. Nemkova ${ }^{1,2}$, N.N. Zavadenko ${ }^{2}$, O.I. Maslova ${ }^{1}$, G.A. Karkashadze ${ }^{1}$ \\ ${ }^{1}$ Scientific Center of Children's Health, Moscow, Russian Federation \\ ${ }^{2}$ Pirogov Russian National Medical Research University, Moscow, Russian Federation
}

\title{
Diagnosis and correction of cognitive disorders in children with traumatic brain injury sequelae
}

\section{Author affiliation:}

Nemkova Svetlana Aleksandrovna, $\mathrm{PhD}$, Professor at the department of neurology, neurosurgery and medical genetics at the pediatric faculty of the Pirogov RNMRU, senior research scientist at the department of cognitive pediatrics at the Research Institute of Preventive Pediatrics and Medical Rehabilitation of the SCCH (Russian Academy of Medical Sciences)

Address: 2/62, Lomonosovskiy Ave., Moscow, 119991; tel.: +7 (985) 921-64-18; e-mail: nemkova-sa@yandex.ru

\section{Article received: 17.01 .2014 . Accepted for publication: 14.05.2014.}

The article is dedicated to the relevant aspects of complex diagnosis and treatment of cognitive disorders in children and adolescents with traumatic brain injury (TBI) sequelae in the long term. Traumatic brain injury is one of the most important issues of the modern neuroscience due to high incidence rate and incapacitation severity. A steady increase in TBI sequelae, many of which are cognitive disorders (cerebro-asthenic and psychoorganic syndromes, post-traumatic dementia) accompanied by various symptoms of vegetative dysfunction syndrome, has been observed in children in the recent years. The factors affecting severity of TBI sequelae in children are severity of the injury, age at the injury, time elapsed since the injury and localization of the lesion. Disturbances of memory and attention (75\%), hand-eye coordination, cerebro-asthenic disorders (88\%) and chronic headaches (95\%) are prevalent in the structure of cognitive disorders after a minor TBI. Severer cognitive dysfunctions accompanied by pathological neurological symptoms resulting in difficulties in learning, self-service and negatively affecting social adaptation in general are observed in 94-100\% of the children having suffered moderate or severe TBI. The article discusses the modern methods of complex diagnosis and pathogenetically substantiated techniques of drug therapy of cognitive disorders in patients with traumatic brain injury sequelae in detail.

Keywords: traumatic brain injury, cognitive disorders, children, post-concussion syndrome, cerebro-asthenic syndrome, post-traumatic encephalopathy.

According to the UN estimates, disabled people comprise $10 \%$ of the total population; diseases of the nervous system (19.5\%) and mental disorders (14.5\%) dominate the structure of children's disability [1-5]. Currently, traumatic brain injury (TBI) is one of the most widespread neurological diseases in children, as the number of people suffering from such disorders annually increases by $2 \% ; 1.5 \mathrm{mn}$ of these people die, $2.5 \mathrm{mn}$ - become disabled [6-8]. TBI prevalence in Europe is $150-300$, in the USA - 200-610, in Russia - 630 per 100, 000 people; the incidence rate increased by $17 \%$ in the last 7 years, while the mortality rate decreased by $46 \%$ [8-12]. The absolute peak of TBI cases is registered in adolescents and young persons; TBIs often result from alcohol intoxication and road traffic accidents [7, 9].

The last decade has been marked by growth of the number of benign outcomes of TBIs; this is largely associated with advancement of intensive care technologies and acquisition of more data on pathophysiology of the acute period of TBIs, especially of severe TBIs (decrease in the mortality rate in the USA and other western countries down to 24-30\%) [10,11]. At the same time, reduction in the duration of inpatient hospital stay in the event of acute TBI and inpatient hospital treatment. Children and adolescents go back come and resume their school studies at an early stage of TBI rehabilitation TBI; this creates prerequisites for development of neuropsychic 
disorders at a later stage: $63-75 \%$ of the children who have had TBIs may develop various conditions, which lead to social deadaptation both in studies and a professional activity [6, 13-16]. Besides, poor performance of the most widely used conventional treatment and rehabilitation methods for the intermediate and late phases of moderate and severe TBIs results in the formation of pathological residual phenomena in $60-90 \%$ of the patients $[14,17-22]$.

The basis for the remote sequelae of TBIs is comprised of such pathological processes as direct injury of the brain matter at the moment of injury, cerebrovascular and cerebrospinal fluid circulation disturbance, cicatrical adhesions and autoneurosensitization [7, 23, 24].

Classification of TBI sequelae has been being developed and is not present in the International Classification of Diseases, Revision No. 10 (ICD-10), and foreign textbooks on TBIs. According to the ICD-10, TBI sequelae are classified under section T90: Sequelae of injuries of head. In Russia, a broader, advanced variant of classification of TBI sequelae was proposed [7, 23]; it takes the following into consideration:

- pathogenetic peculiarities of occurrence;

- clinical forms depending on the predominant morphological alterations;

- major clinical syndrome (vegetative and dystonic, vascular, liquor-dynamic, local cerebral, post-traumatic epilepsy, vestibular, neuroendocrine, asthenic, psychoorganic);

- peculiarities of development (progressive and non-progressive).

The frequency analysis of clinical manifestations of TBI sequelae carried out in compliance with the applicable classification of clinical and functional syndromes [15] demonstrates that asthenic syndrome occurs in $64 \%$ of the patients, vegetative and dystonic syndrome - in $58 \%$, liquordynamic syndrome - in 39\%, local cerebral syndrome - in 36\%, psychopathologic syndrome in $27 \%$, post-traumatic epilepsy - in $12 \%$ [15].

TBI outcomes are the clinical conditions of patients diagnosed 3,6 or 12 months after the TBI and the associated social activity of patients and their ability to work [7, 25].

The Burdenko Institute of Neurosurgery has developed a differentiated scale of TBI outcomes, which distinguished between the following combinations of condition of patients and their ability to work [25]:

- recovery;

- mild asthenia (increased fatigue without memory defects and difficulty concentrating attention; ability to work full-time and perform all functions in the same position; children demonstrate the same level of learning capacity and academic progress as they had before the TBI);

- moderate asthenia with memory defects (work in the same positions, though less productively as in the pre-TBI period; children may feature a slight academic progress degradation);

- severe asthenia (rapid physical and mental fatigability, memory failure, major shortening of attention span; frequent headaches and other uncomfortable manifestations; downgrade to a less qualified work; disability group III; children demonstrate a significant academic progress degradation);

- evident disturbance of mental and/or motor functions (capable of attending to him-/herself; disability group II; children demonstrate evident decrease in learning capacity and require a special school program);

- serious mental, motor and visual disturbances (require personal care; disability group I (adults); children are capable of learning only elementary facts);

- vegetative conditions;

- death.

Variations of clinical progress and TBI outcomes in children are caused by the fact that mechanic energy affects the brain, which has not completed its growth and development. There is an opinion that, clinically, TBIs take a milder course in children than in adults due to low calcination and elasticity of cranial bones, open seams between them, presence of fontanels and incomplete differentiation of the structure of nervous centers and brain circulation systems [6, 13]. While carrying out the analysis of clinical records of children and adults with severe TBIs, foreign researches observed that the mortality rate in children after severe TBIs was $24 \%$, in 
adults $-45 \%$. After TBIs, benign outcomes were registered in $55 \%$ of the children and only $21 \%$ of the adults. Russian researchers also point out that children have a higher chance of benign outcome than adults, even after severe clinical TBIs, due to higher plasticity of a child's developing brain $[6,26,27]$.

Meanwhile, it is known that a mild TBI occurring in childhood can often have long-lasting sequelae $[14,17,22,28,29]$.

The factors affecting severity of TBI sequelae in children include severity of the injury; age at the injury; amount of time that passed after the TBI; injury location [14, 19, 20, 24, 27, 28].

Severity of neuropsychic disturbances in the late TBI period significantly depends on the initial severity of the injury.

The most evident interdependence between clinical form and severity of the TBI is primarily registered in the first post-traumatic year; such interdependence is not observed in the late period; nevertheless, most researchers note that cerebral systems are more likely to produce adequate response in the event of a mild TBI [8, 14, 17, 20]. It has been demonstrated that children with severe TBIs develop at the very least moderate disability in $100 \%$ of the cases, whereas moderate TBIs result in moderate disability only in $65 \%$ of the examined patients [12]. While studying life quality indicators in three groups of adolescents, who had suffered from TBIs 4 years before this study (group 1 - severe TBI, group 2 - moderate TBI, group 3 orthopedic injuries only), it was observed that adolescents from groups 1 and 2 had the lowest life quality indicators in the late TBI period. Low quality of life manifested itself in the failure of general psychosocial functioning due to the problems with behavior, cognitive activity, overall state of health and family relations. Such parameters as communication skills, everyday self-care and general adaptability were also worse in the group of patients with severe TBIs than in the adolescents with orthopedic injuries only [22].

Residual organic disorders after mild TBIs are often considered in the framework of the minimum brain dysfunction caused by functional disturbance of the activating system of reticular formation of anterior parts of the brainstem and subcortical ganglions' nuclei functionally linked therewith [7, 14, 17, 29]. According to the data provided by Russian and foreign researchers, $30 \%$ and $60-80 \%$ of children, correspondingly, develop post-concussion syndrome in the late TBI period marked by decrease in working capacity, memory defects, headaches, dizziness and sleep disorders [7, 14, 17, 29-32]. Some authors point out that one third of the patients who have had a mild TBI have a below the average intelligence quotient, and more than one half of the patients are not capable of returning to work for a year or more, whereas the structure of cognitive disorders is dominated by mild cognitive disturbances, which might be accompanied by school study difficulties: defects of memory and attention, inability to quickly shift from one type of activity to another etc. [6, 17, 21]. According to our studies, cerebroasthenic disturbances occur in $64 \%$ of the children, mild disturbances of cognitive functions (verbal intelligence decrease by $20.5 \%$, non-verbal - by $11.6 \%$; accompanied by residual neurological disturbances of muscular tone, coordination, craniocerebral innervation) in $33-64 \%$ [14].

Moderate and severe TBIs cause severer sequelae, which might manifest themselves not immediately, but remotely. TBI affects the normal course of brain development processes; as a result, child's personality development, his/her cognitive and emotional development, school studies and social skills formation are affected. After moderate TBIs, regression of pathological neurological symptoms is observed in $60 \%$ of the records, stabilization - in $30 \%$, aggravation in $10 \%$ [21]. An obligatory feature of a traumatic disease after a moderate TBI is a disorder of non-specific brain systems, which causes psychovegetative syndrome, which significantly influences the clinical pattern, the course of the post-traumatic period and social adaptation of patients $[15,18,21]$. It is a well-known fact that stabilization is observed in not more than $41.7 \%$ of the cases of severe TBI; besides, a large number of adverse outcomes is registered [7, 21]. It has been demonstrated that moderate and severe TBIs result in cerebroasthenic syndrome occurs in $94 \%$ of the children, in school study difficulties - in $93 \%$, in sleep disorders - in $84 \%$, 
in shortening of attention span - in $96 \%$, in memory defects - in $78 \%$, in motor awkwardness in $63 \%$, in speech disturbances - in $40 \%$. Coordination in adolescents with moderate and severe TBIs is 2.6 and 4 times worse than in their healthy peers [13, 14, 16, 18-20].

Severe TBI outcomes vary considerably. It has been demonstrated that the children who suffered from a severe TBI before the age of 5 years tend to develop motor and cognitive disturbances. Examination of 238 patients aging from 4-14 years (for at least 6 months and up to 4 years) after closed moderate and severe TBIs revealed disturbances of motion coordination in $100 \%$ of the cases, attention and memory disorders - in $75 \%$ of the cases, speech disorders - in $14 \%$ of the cases, cerebroasthenic symptoms - in $88 \%$ of the cases, chronic post-traumatic headaches - in $96 \%$ of the cases $[14,16-21]$.

Analysis of sequelae of 345 cases of severe and extremely severe TBIs in children and adolescents under 18 years of age demonstrated that $73 \%$ of the patients were able to move unassistedly and fully attend to themselves, $10 \%$ featured motion restrictions and partly depended on other people in terms of self-service; $9 \%$ of the patients recovered consciousness, yet remained entirely dependent on other people in the late TBI period [13, 33].

Pathological neurological symptoms after moderate and severe TBIs develop in $92-100 \%$ of the children; they are aggravated by psychoorganic syndrome symptoms combined with the decrease in intellectual and mnestic functions in $90 \%$ of the patients, speech disorder - in $78-94 \%$ of the patients; this leads to the failure of social adaptation, including learning capacity $(36-62 \%)$ and self-service (62-83\%) [14].

The question whether the age at TBI influences clinical manifestations as much as TBI severity has been actively discussed, as it is a well-known fact that the functions developing at the time of a TBI may suffer worse than those which had formed before the TBI [2, 6, 27, 34, 35]. That is why the child's age at the time of injury is an important factor affecting sequelae of the injury $[33,35]$.

It has previously been believed that children and adolescents are more capable of recovering disturbed functions after TBIs than adults (the younger the age at TBI, the higher the chance of complete regression of neurological disorders); however, results of special studies turned to be less optimistic [14, 35-37]. Although the survival rate after severe TBIs among pediatric patients is indeed higher than among adults, residual neurological disorders tend to persist in many children in the late period of moderate and severe TBIs. Many researchers note that the TBI suffered in the childhood negatively affects further differentiation of functions of the central nervous system (CNS); TBI sequelae aggravate with age [14, 17, 19, 36, 37].

Brain injuries in the primary school age and adolescence, when brain structuring and development of most of functional systems thereof have completed (except for hypothalamus nuclei), in most cases cause disorders of functional interconnection of anterior parts of the brainstem and hemispheres as well as disturbed regulation of vegetative processes, which results in cerebroasthenic conditions [6, 14-17]. Other researchers place more emphasis on cortical location of the organic disorder of the brain $[6,14,38]$.

It has been proved that adolescents and adults recover neurological functions after sever TBIs with equal effectiveness [34]. Other scientists assume that adolescents are capable of a relatively fast recovery of motor and sensory functions even after severe TBI (just like children) [39]. Other neurological disorders commonly include speech and sight impairment and sleep disorders $[17,19,21]$.

Cognitive sequelae of TBIs have been recently distinguished into a special group. At the same time, it is emphasized that good recovery of the functions disturbed at the acute TBI stage is not a criterion of a favorable prognosis, as it must take into account condition of the higher mental functions in the late TBI period [14, 16, 17, 19, 40, 41].

According to the ICD-10, cognitive disorders after TBIs are classified in the framework of post-concussional syndrome (F07.2).

There are three levels of post-traumatic cognitive disorders [14, 16, 39]:

1) traumatic encephalasthenia (dynamic functional disorders); 
2) traumatic encephalopathy (memory and intelligence disorders, affective disorders);

3) traumatic dementia.

Severity of cognitive disorders in the late TBI period largely depends on the initial severity of the injury. A number of disorders of the higher mental functions are conditioned by specific location of traumas, particularly, of the predominating trauma in the event of cerebral contusions (frontal and temporal lobes). Cognitive disorders occurring in the patients who have had a TBI often affect such spheres of mental activity as memory, attention, information processing rate and control functions provided by prefrontal areas of cerebral hemispheres: planning, organization, decision-making. Nevertheless, in most cases, residual disorders are caused by diffuse involvement of the cortex and injuries of the brain axial structures modulating functional activity of the cortex. This is the combination of injuries of local cortical, axial and subcortical structures that causes memory and attention problems, disorders of regulation of mental activity, emotions and motivation $[7,17,18]$.

Decreasing speed of intellectual processes and difficulties of organization and management of complex information refer to the two permanent manifestations of TBI sequelae $[17-20,25,26]$. Due to them, patients experience difficulty coping with tasks in the dynamic and complicated atmosphere of a classroom at a secondary or high school, which is why return to learning and social life after a TBI is associated with high fatigability, superexcitation and emotional stress. The activity, that used to be natural, would require longer processing, planning and even involve assistance. A child feels uncomfortable about the speed of the educational process during classes, feels isolated and lagging behind due to inability to handle the requirements and process information from several sources simultaneously; a child has a strong fear that he/she will not make outstanding academic progress any more.

Psychoorganic syndrome, which often develops after a moderate or severe TBI, manifesting itself with intellectual and mnestic disorder, critical thinking and emotional disturbances is of high significance $[14,25,26]$.

Some scientists observed total cognitive deficit after severe TBIs [7, 14, 25]; it important to preserve frontal lobes for the recovery of intellectual functions [31, 38].

The most persistent cognitive disorders in children with TBI sequelae are memory, attention and planning (control functions) disorders.

Memory defects are considered characteristic of the patients who have had TBIs regardless of their age $[17,18,32,35]$. According to the data provided by foreign scientists, memory disorders are registered in the overwhelming majority of school children after TBIs; the best recovery results are observed within 4 post-traumatic months, less evident - after one year $[36,37]$.

Comparison of visual and audio-verbal memory of children and adolescents in the late severe TBI period demonstrated that adolescents feature more pronounced and persistent disorders of audio-verbal memory than children, whereas visual memory disorders do not depend on age. According to the authors, the reason is that inferior cortical parts responsible for visual memory largely complete development by 6 years of age, whereas cerebral structures responsible for audio-verbal memory continue developing [32].

Parents and teachers often report memory and attention disorders in the late TBI period in children and adolescents. Attention disorders affect both everyday behavior and learning process. It has been established that children and adolescents with TBIs face the worst difficulties when completing lengthy tasks requiring constant attention concentration. External events and personal thoughts impede concentration. At school, they are unable to follow long-term instructions; at home, where the activities are usually less structured than at school, parents observe that children are unable to keep on performing one task for a long period of time [35].

Post-traumatic epilepsy is a serious neurological TBI sequela; it often aggravates manifestations of cognitive disorders. It has been demonstrated that $5.7 \%$ of $4-14$-year-old patients develop symptomatic post-traumatic epilepsy within one year after a moderate or severe closed TBI [18]. Electroencephalography (EEG) revealed latent epileptiform activity in $37 \%$ of the examined adolescents with TBI sequelae [18-20]. The data on pathogenic impact of the persistent 
epileptiform activity even in the absence of epileptic episodes on the CNS have been accumulated in recent years. It has been established that latent epileptiform activity negatively affects divided and focused attention, kinesthetic and visual memory, motility and coordination. This indicates the need in long-term neurological follow-up of the adolescents who have had TBIs with repetitive EEG tests [18-20].

Emotional and behavioral disturbances in children and adolescents in the late TBI period are difficult to distinguish, as they are closely interconnected. Traumatic encephalasthenia is characterized by apparent emaciation and irritability (may sometimes develop into affective explosiveness) dominating its pattern. It is often accompanied by symptoms of hysteria, neurasthenia, hypochondria and depression. The frequently detected symptoms include kinetic disinhibition, impulsiveness, inability to follow instructions given by adults and perform certain tasks (or a rejection to perform tasks at all). Residual effects of traumatic brain injuries may serve as predisposing factors of psychogenic and neurotic disorders, when a child or an adolescent is experiencing a difficult situation. They also contribute to pathological personality development. Emotional and behavioral disturbances in the late TBI period hinder social communication and relationships with peers $[6,13,19]$.

Diagnosis of cognitive disorders in children and adolescents affected by TBIs give specific attention to identifying disorders of memory, attention and control functions. The most frequently employed diagnostic techniques include Burdon Attention Test, Stroop's Test, Mini-Mental State Examination (MMSE), Frontal Assessment Battery (FBA) and Paced Auditory Serial Addition (PASAT). The techniques employed to perform a complex clinical assessment include Clinical Interview Based Impression of Change Plus and Global Deterioration Rating; motility and coordination are assessed using Dencla's method [41, 42]. Achenbach's and Zavadenko's questionnaires may be used to poll parents [43, 44].

It is strongly advised to actively treat cognitive, emotional, and behavioral disturbances in children with TBI sequelae both in the first post-traumatic year, when rehabilitation effectiveness is the highest, and after that, taking into account development and flexibility of a child's CNS. Drug-induced therapy is the predominant type of therapy [8, 45-48].

Cognitive disturbances at the acute stage of mild TBI in children have been treated successfully with a combination of Actovegin and Ceraxon [29]. Cerebrolysin has been proven efficient for post-TBI cognitive disorder treatment $[16,18,49,50]$.

Intake of $\geq 2 \mathrm{~g}$ of piracetam per day resulted in positive memory and attention recovery effect in $79 \%$ of the children aging from 7 to 12 years with mild TBI sequelae; intake of $1.2 \mathrm{~g}$ per day - in $30 \%$ of the children (and only $20 \%$ in the control group), as well as in $60 \%$ of the piracetam-taking adolescents with moderate or severe TBIs sequelae (only $5 \%$ in the control group) $[16,48]$.

The positive experience of the combined treatment of cognitive disorders in children in the mild TBI period using deproteinized hemoderivative of calf blood (Actovegin) and citicoline (Tserakson) is demonstrated [29].

Cortexin - a complex neuropeptide drug - has been successfully utilized to treat TBIs and sequelae thereof in children and adults for over 20 years [24, 51-57]. A range of clinical studies have demonstrated high effectiveness of this nootropic drug for recovering cognitive functions in the late TBI period [24, 52-55].

66 children aging from 1 to 15 years with closed TBI sequelae were followed up in order to estimate their attention function (Burdon Attention Test), EEG dynamics and BB-isozyme creatine phosphokinase $(\mathrm{CPK})$ brain fraction (which correlates with neuronal metabolic disturbance). It has been revealed that taking Cortexin improves attention by $39 \%$, which is 1.5 times better than the results of conventional treatment. $62 \%$ of the patients displayed a reduction in the CPK-BB level in blood, 76\% - positive EEG dynamics, $70.2 \%$ - good result of vegetative disorder corrective measures (twice as good as in the control group) [24].

Examination of 187 patients with TBI sequelae indicated that the nootropic drug contributed to positive dynamics of cognitive function recovery (memory, attention, visual-motor coordination) 
in $61 \%$ of the patients; $49 \%$ of the patients demonstrated positive EEG dynamics, $40 \%$ - brain blood circulation improvement (rheoencephalography) [53]. The study also demonstrated positive experience of using Cortexin to treat chronic post-traumatic headaches in children [51]. In recent years, researchers have started to give their attention to biochemical shifts caused by TBIs accompanied by decrease in synaptic transmission effectiveness and development of glutamate exitotoxicity due to excessive glutamate release conditioned by hypoxia and energy deficit, as well as by secondary accumulation of free radicals and neurodegeneration. This is why correction of biochemical changes is one of the most promising trends of cognitive disturbance pharmacotherapy in patients with TBI sequelae [47, 48, 58].

Amantadine (NMDA-glutamate receptor antagonist, dopamine agonist) features a proven positive impact on cognitive function (memory and attention) recovery in adolescents if the intake started at the acute TBI stage and continued for at least 2 weeks [59].

Cytoflavin [60] and Phenotropil have displayed a more prominent positive effect on correction of memory and attention disorders in patients with TBI sequelae than that achieved with Piracetam [61]. Noopept intake also resulted in cognitive function improvement in patients with mild and moderate TBI sequelae [48]. A double-blind study demonstrated a positive result of treating cognitive disorders with acetylcholinesterase inhibitors, i.e. galantamine derivatives (donepezil, rivastigmine). The result lasts long after treatment withdrawal [62].

Differentiated approach to diagnosis and treatment of cognitive disorders improves effectiveness of complex rehabilitation and social adaptation of children with traumatic brain injury sequelae.

\section{REFERENCES}

1. Baranov A. A., Al'bitskii V. Yu. Osnovnye tendentsii zdorov'ya detskogo naseleniya Rossii [Main Tendencies of Children's Health in Russia]. Moscow, 2011. 116 p.

2. Baranov A. A., Maslova O. I., Namazova-Baranova L. S. Vestnik rossiiskoi akademii meditsinskikh nauk - Annals of the Russian Academy of Medical Sciences. 2012; 8: 26-33.

3. Karkashadze G. A., Maslova O. I., Namazova-Baranova L. S. Pediatricheskaya farmakologiya - Pediatric pharmacology. 2011; 8 (5): 6-12.

4. Nemkova S. A. Kognitivnye narusheniya pri detskom tserebral'nom paraliche [Cognitive Disorders at Cerebral Palsy]. Moscow, Triada-Kh, 2013. 440 p.

5. Nemkova S. A. Detskii tserebral'nyi paralich: sovremennye tekhnologii v kompleksnoi diagnostike i reabilitatsii kognitivnykh rasstroistv [Cerebral Palsy: Modern Technologies of Complex Diagnosis and Rehabilitation of Cognitive Disorders]. Moscow, Medpraktika-M, 2013. $440 \mathrm{p}$.

6. Artaryan A. A., Iova A. S., Garmashov Yu. A., Banin A. V. Cherepno-mozgovaya travma u detei: Klinicheskoe rukovodstvo [Traumatic Brain Injury in Children: Clinical Guideline]. Moscow, Antidor, 2001.

7. Konovalov A. N., Likhterman L. B., Potapov A. A. et al. Klinicheskoe rukovodstvo po cherepno-mozgovoi travme [Clinical Guideline on the Traumatic Brain Injury]. Moscow, 1998.

8. Christianson J., Phelps J. Assessment and treatment of the pediatric traumatic brain injury patient. Nurs Spectr Wash-D-S. 1998; 30 (24): 12-14.

9. Valiullina S. A., Roshal' L. M., Al'bitskii E. V. et al. Cherepno-mozgovaya travma u detei: epidemiologicheskie i sotsial'nye osobennosti. V kn.: Aktual'nye problemy sotsial'noi pediatrii: izbrannye ocherki. Pod. red. V.Yu. Al'bitskogo [Traumatic Brain Injury in Children:

Epidemiological and Social Characteristics. In the book: Actual Problems of Social Pediatrics: Selected Essays. Edited by V.Yu. Al'bitskii]. Moscow, 2012.

10. Bawden H. N., Knights R. M., Winogren H. W. Speeded performance following head injury in children. J Clinical and Experimental Neuropsychology. 1985; 7: 39-54.

11. Faul M., Xu L., Wald M. M., Coronado V. G. Traumatic in the United States: emergency department visits, hospitalizations, and deaths. Atlanta (GA). Centers for Disease Control and Prevention, National Center for Injury Prevention and Control. 2010. 
12. Kraus J. F. Epidemiologic features of brain injuries in children: occurrence, children in risk, causes and manner of injury, severity and outcomes. Traumatic Head Injury in Children. Eds. S. H. Broman, M. E. Michel. New York: Oxford University Press. 1995. P. 5-21.

13. Maas A. I. R., Stocchetti N., Bulloc R. Moderat and severe traumatic brain injury in adults. Lancet Neurol. 2008; 7 (8): 728-741.

14. Nemkova S. A. Reabilitatsiya s ispol'zovaniem kosmicheskikh tekhnologii detei s posledstviyami cherepno-mozgovoi travmy [Rehabilitation of Children with Traumatic Brain Injury Sequellae using Space Technologies]. Mosocw, Medpraktika-M, 2002. 220 p.

15. Odinak M. M., Emel'yanov A. Yu. Voenno-meditsinskii zhurnal-Militaty medical journal. 1998; 1: 46-51.

16. Guzilova L. S. Posledstviya tyazheloi zakrytoi cherepno-mozgovoi travmy i otsenka effektivnosti ee lecheniya nootropnymi preparatami u podrostkov. Avtoref. dis. ... kand. med. nauk: 14.00.13 [Sequelae of a Severe Closed Traumatic Brain Injury and Evaluation of Nootropic Treatment Effectiveness in Adolescents. Author's abstract]. Moscow, 2008. 30 p. 17. Zavadenko N. N., Petrukhin A. S., Sokolova T. V. Vestnik prakticheskoi nevrologiiBulletin of practical neurology. 1997; 3: 80-85.

18. Zavadenko N. N., Kemalov A. I. Vestnik prakticheskoi nevrologii-Bulletin of practical neurology. 2003; 7: 44-50.

19. Zavadenko N. N., Kemalov A. I., Guzilova L. S. et al. Lechashchii vrach-Practicing doctor. 2005; 6: 1014.

20. Zavadenko N. N., Kemalov A. I. Voprosy sovremennoi pediatrii-Current pediatrics. 2006; 5 (4): 14-21.

21. Shogam I. I. Zhurn. nevrologii i psikhiatrii im. S. S. Korsakova-S.S. Korsakov Journal of neuropathology and psychiatry. 1989; 89 (5): 141-145.

22. Stancin T., Drotar D., Taylor H. G., Yeates K. O., Wade S. L., Minich N. M. Health-related quality of life of children and adolescents after traumatic brain injury. Pediatrics. 2002; 109: 210.

23. Makarov A. Yu. Nevrologicheskii zhurnal-Neurological journal. 2001; 6 (2): 38-42.

24. Platonova T. N. Terapevticheskaya korrektsiya otdalennykh posledstvii priobretennykh entsefalopatii u detei. Avtoref. dis. ... kand. med. nauk [Therapeutic Correction of Long-time Consequences of Acquired Encephalopathy in Children. Author's abstract]. St. Petersburg, 1998. $24 \mathrm{p}$.

25. Dobrokhotova T. A. Neiropsikhiatriya [Neuropsychiatry]. Moscow, 2013. 304 p.

26. Zaitsev O. S. Psikhopatologiya tyazheloi cherepno-mozgovoi travmy [Psychopathology of Severe Traumatic Brain Injury]. Moscow, MedPressInform, 2011. 336 p.

27. Kazakov V. E. Mezhdunarodnyi nevrologicheskii zhurnal - International neurological journal. 2013; 7 (61).

28. Thornhill S., Teasdale G. M., Murray G. D., McEwen J., Roy C. W., Penny K. I. Disability in young people and adults one year after head injury: prospective cohort study. BMJ. 2000; 320: $1631-5$.

29. Drozdova E. A. Farmateka - Pharmateca. 2011; 14: 60-64.

30. Howell D., Osternig L., van Donkelaar P., Mayer U., Chou L. Effects of Concussion on Attention and Executive Function in Adolescents. Med Sci Sports Exer. 2013; 45 (6): 10231029.

31. Levin H. S., Ewing-Cobbs L., Eisenberg H. M. Neurobehavioral outcome in pediatric closed head injury. In: Traumatic Brain Injury in Children. Eds. S. H. Broman, M. E. Michel. Oxford Press. 1995. P. 70-94.

32. Max J. E. Attention - deficit hyperactivity symptomatology after traumatic brain injury: a prospective study. J. E. Max, S. Arndt, C. S. Castillo, H. Bokyra et al. J Am Acad Child Addesc Psychiatry. 1998; 37 (8): 841-847.

33. Ermolaev A. I., Shklovskii V. M. K probleme sotsial'noi adaptatsii bol'nykh s posledstviyami cherepno-mozgovoi travmy. Materialy 3-i nauchno-prakticheskoi konferentsii, posvyashchennoi 
30-letiyu gorodskoi bol'nitsy № 10 [On the Problem of Social Adaptation of Patients with Sequelae of Traumatic Brain Injury. Proceedings of the 3rd Scientific-practical Conference dedicated to the 30th Anniversary of the City Hospital № 10]. Moscow, 1996. pp. 17-19 34. Wilson B., Vizor A., Bryant T. Predicting severity of cognitive impairment after severe head injury. Brain Injury. 1991; 5: 189-197.

35. Dennis M., Guger S., Roncadin C., Barnes M., Schachar R. Attentional inhibitory control and social-behavioral regulation after childhood closed head injury: do biological, developmental, and recovery variables predict outcome? J Int Neuropsychol Soc. 2001; 7: 683692.

36. Bara B. G. Cognitive Pragmatics. The mental processes of communication. MIT Press, Cambridge MA. 2010.

37. Middleton J. A. Practitioner review: Psychological sequelae of head injury in children and adolescents. J Child Psychol Psychiat. 2001; 42: 165-180.

38. Levin H., Chapman S. Contribution of frontal lobe lesions to cognitive deficit after closed head injury in children. In: Localisation of brain lesions and developmental functions. Eds. D. Riva, A. Benton. Pediat Neurol Ser (Milan). 2000; 9: 97-108.

39. Teasdale T. W., Endberg A. W. Cognitive dysfunction in young men following head injury in childhood and adolescence: a population study. J Neurol Neurosurg Psychiat. 2003; 74: 933936.

40. Zavadenko N. N., Guzilova L. S. Pediatriya. Zhurnal im. G. N. SperanskogoPEDIATRIYA-MOSCOW. 2012; 91 (1): 81-88.

41. Melikyan Z. A., Mikadze Yu. V., Potapov A. A. et al. Zhurn. nevrologii i psikhiatrii im. S. S. Korsakova - S.S. Korsakov Journal of neuropathology and psychiatry. 2011; 111 (7): 88.

42. Denckla M. B. Revised neurological examination for subtle singns. Psychopharm Bull. 1985; 21: 773-789.

43. Achenbach T. M. Manual for the Child Behavior Checklist. Burlington, University of Vermont Department of Psychiatry. 1991.

44. Zavadenko N. N. Giperaktivnost' $i$ defitsit vnimaniya $v$ detskom vozraste [Hyperactivity and Attention Deficit Disorder in Children]. Moscow, Academy, 2005. 236 p.

45. Verizhnikova E. V., Sholomov I. I. Medikamentoznaya optimizatsiya korrektsii cherepnomozgovoi travmy u detei i podrostkov. Reabilitatsionnye tekhnologii XXI veka [Drug Optimization Correction of Traumatic Brain Injury in Children and Adolescents. Rehabilitation Technologies of the $21^{\text {st }}$ Century]. Saratov, 2006. pp. 26-27.

46. Vorob'ev S. V., Odinak M. M., Emelin A. Yu. et al. Voenno-meditsinskii zhurnal-Militaty medical journal. 2011; 1: 17-23.

47. Melikyan Z. A., Zaitsev O. S., Mikadze Yu. V., Potapov A. A. Zhurn. nevrologii i psikhiatrii im. S. S. Korsakova - S.S. Korsakov Journal of neuropathology and psychiatry. 2012; 4: 89-95. 48. Odinak M. M., Vorob'ev S. V., Lobzin V. Yu., Emelin A. Yu., Kudyasheva A. V. Zhurn. nevrologii i psikhiatrii im. S. S. Korsakova - S.S. Korsakov Journal of neuropathology and psychiatry. 2011; 111 (9): 7376.

49. Zavadenko N. N., Guzilova L. S., Iznak A. F., Iznak E. V. Nevrologicheskii vestnikNeurological bulletin. 2008; 15: 64-71.

50. Litovchenko T. A., Laktanova O. A., Kurlyak E. A. et al. Nevrologiya-Neurology. 2010; 316.

51. Bazarnaya N. A. Khronicheskaya posttravmaticheskaya golovnaya bol'u detei. Avtoref. dis. ... kand. med. nauk [Chronic Posttraumatic Headache in Children. Author's abstract]. 2004. 26 p. 52. Golovkin V. I., Bitsadze A. N. Vestnik gipnologii i psikhoterapii-Bulletin of hypnology and psychotherapy. 1991; 1: 49-50.

53. Emel'yanov A. Yu., Emelin A. Yu., Bitsadze A. N. Vestnik Rossiiskoi voenno-meditsinskoi akademii - Bulletin of the Russian Military Medical Academy. 2004; 2 (12): 74-76.

54. Emel'yanov A. Yu. Meditsinskii vestnik-Medical bulletin. 2007; 2. 
55. Nemkova S. A., Maslova O. I., Karkashadze G. A. et al. Pediatricheskaya farmakologiya Pediatric pharmacology. 2012; 5.

56. Nemkova S. A., Maslova O. I., Karkashadze G. A., Zavadenko N. N., Kurbatov Yu. N. Pediatricheskaya farmakologiya - Pediatric pharmacology. 2012; 9 (3): 77-84.

57. Nemkova S. A., Maslova O. I., Zavadenko N. N., Karkashadze G. A. Detskaya $i$ podrostkovaya reabilitatsiya - Child and adolescent rehabilitation. 2012; 1: 4-15.

58. Parsons C., Danysz W., Hesselink M. et al. Modulation of NMDA receptors by glycineintroduction to some bacis aspects and recent developments. Amino Acids. 1998; 14 (1-3): $207-$ 216.

59. Kraus J. F., Maki P. M. Effect of amantadine hydrochloride on symptoms of frontal lobe dysfunction in brain injury: case studies and review. J Neuropsychiatry and Clinical Neuroscience. 1997; 9: 222-230.

60. Skoromets A. A., Pugacheva E. L. Zhurn. nevrologii i psikhiatrii im. S. S. Korsakova - S.S. Korsakov Journal of neuropathology and psychiatry. 2010; 110: 3.

61. Chikina E. S., Levin V. V. Russkii vrach - Russian doctor. 2005; 11.

62. Silver J. M., Koumaras B., Meng X., Potkin S. G., Reyes P. F., Harvey P. D., Katz D. I., Gunay I., Arciniegas D. B. Long-term effects of rivastigmine capsules in patients with traumatic brain injury. Brain Injury. 2009; 23 (2): 123-132. 